\title{
Chemical Castration for Pedophiles: Study of Fiqh Problems in Indonesia
}

\author{
Azhari Akmal Tarigan \\ Universitas Islam Negeri Sumatera Utara - Indonesia \\ email: azhariakmaltarigan@uinsu.ac.id
}

\begin{abstract}
Chemical castration is a punishment against pedophiles, who have committed acts of crime that are considered an extraordinary crime. Pedophiles have ruined the future of children, with tremendous psychological and environmental impacts. This paper aims to uncover the problems of figh in Indonesia concerning chemical castration which has the aim of providing a deterrent effect for rape perpetrators of children. The data collection method in this study uses the literature study. There are differences in the views of legal experts with doctors. Legal experts decide on penalties for pedophiles with Law Number. 17 of 2016 concerning the Second Amendment to Law Number. 23 of 2002 concerning Protection of Children, while the Indonesian Doctors Association states reject chemical castration punishment, following the Code of Ethics as stated in the rules of the Medical Code of Ethics Assembly (MKEK) Number. 1 of 2016 concerning Chemical Castration. Fiqh experts disagree over the castration penalty for chemistry. There is no castration punishment in the figh, because the Prophet Muhammad forbade castration, as opposed to Islamic principles. Some fiqh experts agree that chemical castration punishment includes $t a^{\prime} z \bar{r}$, which is a sentence handed over entirely to the legitimate government. Thus, although the castration chemical punishment has been determined, in its implementation there are problems because there are still rejections and problems according to the fiqh expert
\end{abstract}

Keywords: pedophiles; chemical castration; fiqh

\section{[]}

Penelitian ini bertujuan untuk mengungkap problematika figh di Indonesia dalam kaitannya dengan kebiri kimia yang sebenarnya memiliki tujuan untukmemberikan efek jera bagi pelaku perkosaan terhadap anak-anak. Metode pengumpulan data dalam kajian ini mengunakan studi kepustakaan dengan mengkaji berbagai literatur yang ada. Terdapat perbedaan pandangan para ahli hukum dengan para dokter. Ahli hukum memutuskan hukuman kebiri kimia bagi pedofil dengan Undang-Undang No. 17 Tahun 2016 tentang Perubahan Kedua atas Undang-Undang No. 23 tahun 2002 tentang Perlindungan Anak, sedangkan Ikatan Dokter Indonesia menyatakan menolak hukuman kebiri kimia, sesuai dengan Kode Etik sebagaimana tercantum di dalam aturan Majelis Kode Etik Kedokteran (MKEK) No. 1 Tahun 2016 tentang Kebiri Kimia. Para ahli fiqh berselisih pendapat tentang hukuman kebiri kimia. Di dalam figh tidak dijumpai hukuman kebiri, sebab Nabi Muhammad, melarang kebiri, karena bertentangan dengan prinsip Islam. Sebagian ahli fiqh bersepakat bahwa hukuman kebiri kimia termasuk hukuman ta'zir. Meskipun hukuman kebiri kimia sudah ditetapkan, namun di dalam pelaksanaannya mengalami penolakan dan juga problematika menurut para ahli fiqh.

Kata Kunci: pedopil; kebiri kimia; fiqh 
Azhari Akmal Tarigan

\section{Introduction}

Actually, humans have 3 (three) basic needs in their lives, namely biological needs, social needs, and integrative needs. Biological needs are related to the desire to eat, drink, sexuality, home, clothing and so on. Social needs are the need for friendship, communication, organization and so on. While the integrative needs are the need for love, religion, art and so on. ${ }^{1}$

Lately, there have been reports about chemical castration punishment, which was triggered by the Decree of the District Judge in Mojokerto East Java against pedophiles who have done it a dozen times or more precisely 9 (nine) times. The pedophile is indeed a concern nowadays, especially related to sexual deviations committed. Victims are children who should get protection from him. $^{2}$

Strangely indeed, pedophiles were close to the victims, for example, class teachers, school teachers, even Koran teachers and traders who used to peddle food in the environment of the child. Coordinated by the Ministry of Human Development and Culture (PMK) by involving many ministries in it, for example, the Ministry of Health, the Ministry of Religion, the Ministry of Law and Human Rights, the Police, Attorney, Judiciary and so on. All ministries and government institutions agree on the need for punishment to deter pedophiles. Not just a deterrent but also did not do it again. The sentence made the person "give up" and no longer repeat his actions. This meeting which later resulted in Government Regulation in lieu of Law (PERPPU), Number. 1 of 2016, concerning Child Protection. ${ }^{3}$

The establishment of PERPPU is certainly based on the proposals of all ministries and government institutions that agree that severe penalties against pedophiles are very important. Therefore, it is proposed to be punished severely, maximum punishment and additional punishment, including chemical castration penalties, for perpetrators who are outrageous in carrying out

\footnotetext{
${ }^{1}$ Nur Syam, Madzab-Madzab Antropologi (Yogyakarta: LKiS, 2007).

2 M.liputan6.com, 'PN Mojokerto: Castration Sentence Against Child Rapists with Law', Surabaya.Liputan6.com, n.d.

3 President of the Republic of Indonesia, 'Government Regulation in Law of The Republic of Indonesia Number 1 of 2016 Concerning The Second Amendment to Law Number 23 of 2002 Concerning Child Protection' (2016).
} 
deviant sexual behavior, for example, these actions are carried out repeatedly with different quantities and perpetrators of victims. This Government Regulation in Lieu of Law (PERPPU) was later strengthened by the issuance of Law Number. 17 of 2016 concerning the Second Amendment to Law Number. 23 of 2002 concerning Child Protection.

The case that attracted the attention of observers and legal practitioners was the severance of the castration penalty for pedophiles in Mojokerto District, Aris, who had committed 9 (nine) rapes. Aris, 20, is from Mengelo Hamlet, Sooko District, Mojokerto Regency. He was arrested by the police on October 26, 2018, after his last action was captured by CCTV while raping a minor in the housing complex in sub-district of Prajurit Kulon, Mojokerto City. Aris was found guilty based on article 76 D junto Article 81 Paragraph (2) of the Republic of Indonesia Law Number. 23 of 2002 concerning Child Protection with a sentence of 12 years in prison and a fine of Rp. 100 million subside 6 months confinement. Also, Aris was subjected to chemical castration punishment. ${ }^{4}$

Chemical castration punishment becomes the pros and cons. Judge's decision at the Mojokerto District Court turned out to provoke the pros and cons. Chemical castration punishment was rejected by human rights activists and also the Indonesian Doctors Association (IDI). Doctors from IDI questioned castration punishment because the sentence did not guarantee that someone would be able to stop sexual behavior from deviating him. Castration punishment is considered unable to guarantee the desire and potential of the offender not to repeat his actions. IDI also considers that chemical castration is contrary to the Professional Code of Ethics of Doctors. The Code of Ethics is as stated in the rules of the Medical Code of Ethics Assembly (MKEK) Number. 1 of 2016 concerning Chemical Castration, which is also based on a doctor's oath as well as the Indonesian Medical Ethics Code (KODEKI). Meanwhile, human rights activists also reject chemical castration sentences which he considers to be a setback in the determination of legal decisions. Further, it is also explained that better punishment is needed, for an example life sentence for social work. ${ }^{5}$

\footnotetext{
${ }^{4}$ Imanuel Nicolas Manafe, 'For the First Time in Mojokerto, Judge Sentenced to 9 Child Rapists with Chemical Castration Punishment', Tribunnews.com, n.d. n.d.

5 Jawa Pos, 'Police Check the Mental Condition of Bang Jack, Predator 19 Children in Tulungagung',
} 
Another case that is also being investigated by the Police is a case that occurred in Trenggalek. If the case in Mojokerto is related to the rape of 9 (nine) children, the case in Trenggalek is even greater because of the rape of 19 children. Bang Jack (42 years) has raped these children since 2008. The difference is that these rape victims are boys because Bang Jack is a homosexual offender. And the "terrible" that the victims then vent to others as an attempt to revenge. ${ }^{6}$

The controversy about chemical castration punishment is interesting to study, not only from the political dimensions of law, criminal law and also human rights but also from figh problems in Indonesia. Therefore, this paper aims to uncover the problems of fiqh in Indonesia concerning chemical castration which has the aim of providing a deterrent effect for rape perpetrators of children.

This study uses the perspective of fiqh. However, it certainly cannot deny health studies, because what is studied is about chemical castration which is the realm of health science. Therefore, this study will also utilize studies or views of health experts or doctors who understand and can explain the chemical castration. In this context, previous studies will be used both through books, journals, and data that have been disclosed by experts. For the study of jurisprudence, it will utilize library studies focused on the views of fiqh experts (fuqaha ') about the chemical castration. Data collection method in this study uses literature study, utilizing documentary methods, which are sourced from books or fiqh texts that discuss castration punishment, academic journals that discuss castration law, and more specifically chemical castration, and also writings in various media, especially those related to the facts of pedophile behavior, both those who have been convicted by the judiciary and those in police investigations.

Chemical castration studies, mostly in the realm of law. This is certainly a common practice because the most associated with castration chemical punishment is the legal aspect. Among these studies are conducted by Krismiyarsi ${ }^{7}$, which states that violent behavior towards children is increasing

\footnotetext{
${ }^{6}$ Jawa Pos.

7 Krismiyarsi, 'Chemical Castration Sanction Policy for Actors of Sexual Violence against Children, Study of Legal Politics', Unnes 4, no. 1 (2018).
} 
in number from year to year. For this reason, the president issued Government Regulations in lieu of Laws, Number. 1 of 2016 and subsequently increased to Act Number 1 of 2016 concerning Second Amendment to Law Number 23 of 2002 concerning Child Protection. The amendment to the law includes, among other things, the imposition of sentences on rape perpetrators against children in addition to announcing the identity of the perpetrators, and can be subject to chemical castration penalties accompanied by rehabilitation and installation of electronic detection devices. However, the birth of this Act triggered the pros and cons, especially among doctors, especially among the Indonesian Doctors Association (IDI) and also human rights activists.

Nur Hafizal Hasanah's and Eko Supayono' ${ }^{8}$ writings state that the imposition of punishment with chemical castration is contrary to human rights, because based on human rights, and the provisions of article 28G paragraph (2) of the Indonesian constitution state that "everyone has the right to be free from torture and degrading treatment of human dignity ". Nur Qur'ani Mardliya ${ }^{9}$ also examines the behavior of rape against children. In his writings, it is stated that the application of chemical castration punishment causes pros and cons in the community, related to its effectiveness and enactment which is considered to violate human rights as contained in the 1945 Constitution. N. Fitriyani, M. Hamdan and M.Eka ${ }^{10}$ in their writings stated that law enforcement officials must pay very serious attention to the behavior of rape towards children because the consequences of rape are fatal related to the future of the child and also the trauma of the child up to the time front. Law enforcement officers are expected by the community to carry out adequate punishment for acts of sexual crimes or rape behavior towards children so that they will be able to provide a deterrent effect on the perpetrators.

\footnotetext{
${ }^{8}$ Nur Hafizal Hasanah and Eko Soponyono, 'Criminal Law Policy on Chemical Castration Sanctions in the Perspective of Human Rights and Indonesian Criminal Law', Udayana Magister Law Journal 14, no. 1 (2014).

9 Nurul Qur'ani Mardliya, 'The Application of Castration Punishment for Sexual Violence', Constitutional Journal 14, no. 1 (2017).

10 Muhammad Hamdan and Mohammad Eka Nurliza Fitriyani, 'Chemical Castration Acts for Sexual Crimes against Children According to Islamic Law Enforcement Officials', Jurnal Usu, n.d.
} 
In the perspective of $f i q h$, there are also several studies, including Madnur 11 who stated that fiqh law in Islam there is no argument regarding the chemical castration penalty. Chemical castration penalty are still lighter compared to legal sanctions in Islamic criminal law. Another study conducted by Melina Dwi Ratnasari ${ }^{12}$, stated that the chemical castration penalty should be strictly regulated by the government. According to Nahdlatul Ulama (NU) and Muhammadiyah, this punishment is imposed to establish a deterrent effect, also argues that chemical castration punishment is not obtained in the Qur'an or Sunnah. Based on Islamic criminal law, chemical castration punishment is categorized as takzir. According to Muhammad Fathurrahman bin Azizan ${ }^{13}$, that according to ijmak classical clerics forbid castration on humans without any differences and the purpose of its implementation, namely to comprehensively prevent deviant sexual behavior. The opinion is better than chemical castration punishment can be carried out on pedophile behavior and can be categorized as takzir punishment.

Based on the study of Sufyan Ilyas ${ }^{14}$, this study concluded that in Perppu Number. 1 of 2016, that the establishment of chemical castration sanctions for pedophiles is aimed at maintaining the benefit of the Indonesian people, providing a deterrent effect and as a form of a government obligation to the victims. Yusriwanto and Ahmad Mahyani's ${ }^{15}$ study stated that castration punishment as an additional punishment is already relevant to Indonesian criminal law to cause a deterrent effect and the provision of benefits through rehabilitation. Only unfortunately that this additional punishment does not have

\footnotetext{
11 Madnur, 'Castration Sanctions in Indonesia in the Perspective of Islamic Law and Child Protection' (UIN Syarif Hidayatullah, 2019).

12 Melina Dwi Ratnasari, "The Views of Nahdlatul Ulama and Muhammadiyah of East Java on the Implementation of Castration Penalty Sanctions on Pedophilia Actors Based on Law Number 17 Year 2016 and According to Islamic Law' (UIN Sunan Ampel, 2018).

13 Muhammad Fathurrahman bin Azizan, 'Castration Punishment for the Criminals of Pedophilia (Comparative Study of Islamic Law According to Classical Ulama and Perppu Number 1 Year 2018)' (UIN Ar Raniri, 2018).

${ }^{14}$ Sufyan Ilyas, 'Chemical Castration Sanctions for Pedophiles in the Legal Perspective in Indonesia', Al Mursalah Journal 1, no. 2 (2015): 54-62.

${ }^{15}$ Adam Yuriswanto and Ahmad Mahyani, 'Castration Law as Additional Crimes in the Criminal Act of Sexual Crimes', Law Journal of Law 14 (2018): 28-40, https://doi.org/10.5281/zenodo. 1188350.28 .
} 
implementing regulations. Therefore, it is needed a comparison with other countries that also apply castration law as a reference in its implementation.

Based on the studies as mentioned, it can be stated that the study with the theme of this study "Chemical Castration Penalty (Study of Problems of Islamic Law in Indonesia) would be an original study as seen from the absence of reviewers who carried out a more comprehensive review of this from a legal perspective Islam in Indonesia".

\section{Data Description: Pedophilia and Sexual Violence}

\section{Definition of Sexual Violence against Children}

Sexual violence is an act committed by someone or an individual to another, both male and female, which is carried out with an act of violence. The term sexual violence is an act that can be categorized as sexual behavior and sexual relations that are not fair, which causes serious harm to the victims. ${ }^{16}$ It could also be stated as an act of inviting sexual activity without consent. If the object is a child then what is meant is an invitation to engage in sexual activity with someone without the consent he is invited to. Sexual violence is usually carried out with many threats or persuasions that cause a child to be trapped into doing it without he realizes. Sexual violence against children is sexual violence committed by adults against children under the age of between 3 years and 16 years.

The impact of sexual violence on children is depression, post-traumatic stress disorder, anxiety, the tendency to become victims during adult life, and also physical injury to children. Children who have been sexually violated will have a traumatic impact on their lives. These impacts are both permanent and long-term physical and psychological. ${ }^{17}$ For example, feel as a persecuted person, a useless person, a cursed person, a person who is hated by God and society in general, so that then becomes moody, aloof and fearful. He will feel

\footnotetext{
16 Abdul Wahid and Muhammad Irfan, Protection of Victims of Sexual Violence Advocacy for Women's Human Rights, (Bandung: Refika Aditama, 2001).

17 Ni Made Dwi Kristiani, 'Sexual Violence Crimes (Rape) Viewed From a Criminological Perspective', Journal of Magister Hukum Udayana 7, no. 3 (2014).
} 
depressed or excessive fear in navigating his life. If you continue to experience fear then he will be prolonged stress and even result in mental disorders.

This is where the meaning is important to accompany a child who is sexually abused. There must be assistance provided by people close to him so that he does not feel alone in facing his life and also overcoming his problems. Thus the very important help to be given to him is to help him to be able to rise again from adversity so that he can look at his life better.

One form of sexual violence is rape. Rape comes from the Latin word rapere which means to steal, force, seize, or take away. ${ }^{18}$ Rape comes from the basic word "rape" which means forced, strong, and mighty. Rape according to Soetandyo Wignjosoebroto in Suparman Marzuki's book is an attempt to vent sexual appetite by a man towards a woman in a manner that is morally and or in law violates. ${ }^{19}$ Another opinion states that rape is not only the lack of consent of the victim and not only through the vagina but can also be through the mouth and anus. ${ }^{20}$

The National Commission for Women (Komnas) states that rape cases are increasing in Indonesia. 17,088 cases of sexual violence occurred during 20162018. Among the sexual violence cases, there were 8,797 rape cases or 52 percent of the total cases of sexual violence. That is, 8 women were raped every day in the three years. ${ }^{21}$ Cases of sexual violence against children in many cases were carried out by close people, such as teachers. The case in Jombang was a teacher who sexually assaulted 25 students, and in Surabaya, a teacher sexually assaulted 65 students. The perpetrators of the violence were the children's teachers. Strangely, the teacher who perpetrated violence was the one who accompanied students in activities in school.22

\footnotetext{
18 Hariyanto, The Socio-Psychological Impact of Victims of Rape Against Women (Yogyakarta: Pusat Studi Wanita Universita Gajah Mada, 1997).

19 Suparman Marzuki, Sexual Harassment (Yogyakarta: Faculty of Law Indonesian Islamic University, 1997).

20 Made Darma Weda, Criminology (Jakarta: Raja Grafindo Persada, 1996).

21 CNN Indonesia, 'Komnas Perempuan: Every Day, 8 Women Are Raped in Indonesia', CNN Indonesia, n.d.

22 Tirto.id, 'KPAI Highlights Cases of Sexual Violence against Children in East Java during 2018', tirto.id, n.d.
} 
Sexual violence based on the identity of the perpetrators is divided into two categories, namely: First, familial abuse, namely sexual violence, which is between the victim and the perpetrator still in a blood relationship that is part of the nuclear family. Second, extra familial abuse is violence done by others outside the victim's family. Based on data from KPAI in 2014, it showed that children who were victims of sexual violence were $53 \%$ and children as perpetrators $43 \%{ }^{23}$

\section{Pedophilia Cases}

Pedophilia comes from the Greek, from the word paedo which means child and philia which means love. Pedophilia is an adult human who has deviant sexual behavior with children. Pedophilia can be a repetitive sexual fantasy, impulsive desire or sexual behavior involving young children.24 ${ }^{25}$ Pedophilia is an attraction to the sexuality of children which is very large so that it leads the perpetrators to do it even repeatedly. The case of pedophilia in Indonesia is increasingly prevalent. There have been almost all cities in Indonesia. The numerous pedophile cases certainly have upset parents, the observers of the world of children and also the security forces. As we often hear, many people do close to the victim, such as family, neighbors and even the teacher. Whereas the punishment of pedophiles is maximal, for example in Kendari a pedophile was sentenced to 20 years in prison. Adrianus Pattian, the defendant of the Kendari pedophilia case was sentenced to 20 years, fined 1 billion, subside 6 months in prison by the Kendari District Court Judge Council. ${ }^{26}$

This pedophile's behavior is barbaric because he kidnaps a child and then takes him to the forest to have sex. They are 8-10 years old. The five victims were abducted on the highway. The perpetrator threatened with a knife if the victim

\footnotetext{
23 Neng Lani Ligina, Ai Mardhiyah, and Ikeu Nurhidayah, "The Role of Parents in the Prevention of Sexual Violence against Children in Elementary School in the City of Bandung, Ejournal UMM 9, no. 2 (2018): 109-18.

${ }^{24}$ Merriam-Webster, 'Pedophiles Abuse 6 Children in Kendari, This Is Why People Become Pedophiles', n.d.

25 Evy Rachmawati, 'The Dark Side of Tourism on the Island of the Gods', n.d.

${ }^{26}$ Beritatagar.id, 'Pedophiles in Kendari Were Sentenced to 20 Years in Prison', 8 October 2019, n.d.
} 
did not obey his will. In the case in Medan, an 8-year-old girl was raped by her neighbor. ${ }^{27}$ In Bandung there was also a teacher molested 34 of his students. ${ }^{28}$

Based on the theory of need, the desire to sexually abuse children is caused by environmental and biological factors. Unfortunately, the fulfillment of these needs is done by way of deviating. Everyone can meet basic needs, especially biological, such as eating, drinking and also sexuality. However, when the fulfillment of these needs is done in violation of religious, social and legal norms, it is certain that the perpetrator will receive punishment commensurate with his behavior.

The reason people become pedophiles is because of the bad experiences they have had at a young age and the flair of sexuality. In the case of pedophiles, there are indeed those who commit pedophilia because of childhood experiences of being raped (especially for male perpetrators) and also there is indeed a talent or potential for deviant sexual behavior, for example, the sexuality of children. Most who practice deviant sexuality like this is caused by the experience of having sex with children.

The experience of being raped as a child has a big impact on someone. So when there is a child who is raped and then becomes traumatic then he vents his experience to other children. Then for those who have experience raping other people and the experience brings a "fun" experience then they will certainly repeat the experience. That is why there is a perpetrator who rapes young children many times.

\section{Chemical Castration Punishment}

Chemical castration punishment is not unique to Indonesia because some countries in the world have implemented it and even have been enacted for a long time. Chemical castration is an action by injecting anti-testosterone into a man's body to reduce the level of the hormone testosterone which affects a

\footnotetext{
${ }^{27}$ Eko Sutriyanto, 'The Case of Pedophilia Occurred in Medan, the Perpetrator Was Unexpectedly, the Victim's Own Neighbor', 22 January 2019, n.d.

${ }^{28}$ Muhammad Sukardi, “The Case of Teacher Rapes 34 Students in Bandung, Is It True That LeftHanded Men Tend to Be Pedophiles', n.d.
} 
man's sexual desire. ${ }^{29}$ Castration applied in various countries there are 2 kinds. First, physical castration is carried out by amputating the testicles of pedophiles so that it affects their sex drive, as applied in the Czech Republic and Germany. Second, chemical castration is to include anti-androgen chemicals that can weaken the hormone testosterone by taking pills or injections. The effects of chemical castration do not last permanently and if the fluid is stopped, the ability of erections and libido will return to function. The effect of this drug is in the range of 40 hours to 3 months. ${ }^{30}$

In 2011, the South Korean government had a law related to chemical castration. South Korea was the first country to impose chemical castration penalties for pedophiles. On May 23, 2012, a man named Park was sentenced for sexually abusing a child under 16 years of age. And a year later also found a chemical castration sentence against the perpetrators of this crime with a sentence of 15 years in prison plus a castration chemical sentence. ${ }^{31}$

In Russia, there is also a chemical castration penalty, for pedophiles against girls under 14 years of age. Then in Ukraine in 2017 there were 320 cases of rape of children and the rate for sexual abuse was much higher. Another country that expects chemical castration punishment is Kazakhstan, which stated that the number of rapes reached 1000 cases each year from 2010 to 2014. India also applies castration chemical sentences. Since 2012 the Indian government has implemented chemical castration penalties and 30 years imprisonment. Likewise, the UK has also applied chemical castration penalties. In the United States, the first state to impose chemical castration penalties is the State of California. John Money, 53, was the first pedophile to be awarded a chemical castration penalty. John uses medroxy progesterone acetate as a chemical castration instrument. This drug is now commonly used for chemical castration punishment. Then the other states that followed were Florida, Georgia, Iowa, Louisiana, Montana Diego, Oregon, Texas, and Wisconsin. ${ }^{32}$

\footnotetext{
${ }^{29}$ Nur Hafizal Hasanah and Eko Soponyono, 'Criminal Law Policy on Chemical Castration Sanctions in the Perspective of Human Rights and Indonesian Criminal Law'.

30 Nuzul Qur'aini Mardiya, 'Application of Chemical Castration Punishment for Perpetrator of Sexual Violence', The Constitutional Journal 14, no. 1 (2017): 18.

${ }^{31}$ Merdeka.com, 'Cases of Chemical Castration from Korea to the United States', n.d.

32 Merdeka.com.
} 
In Indonesia, the first person to get a chemical castration penalty was Muh.Aris (20 years) a man from Mojokerto, East Java. Chemical castration punishment is an additional sentence after a sentence of 12 years imprisonment, a fine of 100 million subsidiaries 6 months imprisonment. Chemical castration punishment will be carried out at the end of the sentence. He will be castrated with chemistry when the basic sentence is over. According to the General Criminal Section Head of the Mojokerto District Attorney's Office, the determination of the chemical castration sentence was in accordance with the Law. Namely the Law Number. 12 of 2016 concerning Stipulation of Government Regulations in Lieu of Law Number. 1 of 2016 concerning the Second Amendment to Law Number. 23 of 2002 concerning Child Protection becomes a law. According to article 81, A paragraph 1 of Law Number 17 of 2016, the execution of executions for chemical castration convicts will be carried out after the convicted person completes the principal criminal sentence. ${ }^{33}$

In his investigation, Aris (20 years old) frankly stated that he had sexually assaulted. This action was carried out by Aris in four different places, such as the Mangelo mosque, Sooko Mosque, and houses and vacant land in the Sooko Mojokerto sub-district. Aris stated that he did it because of the influence of adult films. He further stated that he also liked adult women but the women did not want to be with him, so he tried it with children by force. ${ }^{34}$

The chemical castration sentence handed down to Aris by the Mojokerto District Court was the first case in Indonesia. However, the punishment that has been inkract cannot yet be carried out because there are no technical guidelines for its implementation. Therefore, the castration chemical penalty is still a dilemma in terms of its implementation aspect. 35

\section{The Problem of Fiqh on Chemical Castration}

Islam is a religion that rahmatan lil 'âlamin and from the beginning was a religion that raised the dignity of humanity as a whole. Therefore the purpose of

\footnotetext{
${ }^{33}$ Kompas.com, 'Chemical Castration for 9 Child Rapists Was Carried out at the End of the Sentence', Kompas.com, 2019.

34 Arif Tio Buqi Abdullah, 'Facts of the Aris Predator Case for Children, Sentenced to Chemical Castration Punishment, Asks to Be Sentenced to Death to File a PK', Tribunnews.com, n.d.

35 Tribunnews.com, "The First Chemical Castration Penalty For Child Rapists Cannot Be Implemented Without Technical Instructions', Tribunnews.com, n.d.
} 
the lawful observance is for the benefit of mankind in achieving happiness in this world and the hereafter. All legal provisions pivoted to five main things called aldarūriya al-khamsa (five main things that must be maintained). Namely protection of religion (hifz al-dīn), protection of souls (hifz al-nafs), protection of reason (hifz al-'aql), protection of offspring (hifz al-nasl), protection of property (hifz al-māl) . Some Jurisprudence experts add hifz al-ird (protection of honor) in addition to the five elements that darūrīi.

Pedophiles who have committed crimes both in the form of rape (heterosexual), sodomy (homosexual), or sexual harassment are categorized as crimes against humanity which according to Islam have violated and threatened things that must be safeguarded in terms of protection of life, mind, descendants, and protection of human honor. Legal sanctions against pedophile perpetrators in Islam have not been specifically published and depend on what he has done to victims and can be included in the scope of ta'zir whose sentence depends on the decision of the ruler or judge.

Based on Perppu Number 1 of 2016, that one of the sentences handed down for pedophilia is a chemical castration penalty. Indonesia, whose majority population is a Muslim, certainly questions the ability of castration punishment in terms of fiqh or Islamic law fiqh al-Jināya or law relating to crime, does not know about castration punishment for pedophiles and the problem is returned to the original law let alone relating to chemical castration.

Castration in fiqh perspective, as explained in the classical books (turāth), the majority of scholars such as al-Qurțubī in al-Jāmi' li Aḥkām al-Qur'ân, Badruddīn al-'Aynī in 'Umda al-Qārī', and Șan'ānī in Subul al-Salam forbid castration for humans, even Ibn Ḥajr al-Asqalānī declared haram based on the ijm $\bar{a}^{\prime}$ of the scholars. Their argument forbidding castration is based on the

\footnotetext{
36 Jasser Auda, Maqasid Al-Shari'ah as Philosophy of Islamic Law: A Systems Approac (Herndon: The International Institute of Islamic Thought, 2010); Ibn Qudamah, Rawdah al-Näzir wa Jannah alManāzair fi Ușūl al-Fiquh (Riyad: Maktabah al-Rushd, 1993); Abū Ishāà Ibrāhīm bin Mūsā Bin Muhammad Al-Shātibīi, Al-Muwāfaqāt fí Ușūl al-Sharīah (Arab Saudi: Dār Ibn 'Affān, 1997); Ahmad alMursi Husayn Jawhar, Maqāsid al-Sharīah fi al-Islām, n.d.; Nurhayati, Modern Age Slavery: Trafficking in Perspectives of Ulama (Medan: Perdana Publishing, 2016); Abū Hāamid Muḥammad Ibn Muhammad Al-Ghazzāili, Al-Mustașfā Min 'Ilm al-Ușūl (Madinah: al-Jāmi'ah al-al-Islāmiyyah, n.d.), vols II, 482; Said Aqiel Siradj, Islam Kebangsaan Fiqh Demokratik Kaum Santri (Jakarta: Pustaka Ciganjur, 1999), 4; Maskur Rosyid, Implementasi Konsep Maslahat al-Tüfi dalam Fatwa MUI (2005-2010), 1st ed. (Magelang: Ngudi Ilmu, 2013), 4.
} 
hadīth of Ibn Mas'ūd which means: "Muhammad ibn 'Abdillāh ibn Numayr alHamdanī told us: My father, Waqi' and Ibn Bishr told us from Ismā'il, from Qays, he said: I heard 'Abdullahh said: We never fought with the Prophet Muhammad without bringing a wife. We asked the Prophet: "Shouldn't we just castrate?" So the Prophet forbade us to do that, he gave us relief to marry a woman with a dowry of cloth for a certain period of time. Then he read to us: "O believers, do not forbid the good that Allah has allowed you to do, and do not transgress. Surely Allah does not like those who exceed the limits" (Al-Māidah: 87)

Based on the above hadith, castration is prohibited because it changes the form Allah created and makes a person unable to have children because castration is done by removing or amputating the testes. Even though the right to have children is a gift from God to every human being that cannot be revoked by anyone for any reason. So, scholars who forbid and prohibit castration perform ijtihād by returning to the original existing law.

As for the chemical castration from the perspective of classical scholars, there is no discussion. Indonesian scholars give different opinions about chemical castration. Mashul Ismail, chairman of the Council of Indonesia Ulama (MUI) of Mojokerto district stated that in a legitimate government, following all existing state regulations is an obligation. All punishments are not humane because crimes committed by one person harm others. Therefore chemical castration punishment to deter the culprit and the person being injected can still be returned to normal conditions so it is not a problem to apply castration chemical punishment. ${ }^{37}$

Ma'ruf Amin, Chairperson of MUI also supports the castration penalty for perpetrators of sexual crimes or pedophiles. He stated that castration punishment was carried out to deter perpetrators and Islam did not recognize the term castration law, it was only ijtihad so that people were afraid to make these provisions. ${ }^{38}$

Bahtsul Masail PW NU East Java on August 29, 2019, decided that the chemical castration criminal law for perpetrators of sexual crimes against

\footnotetext{
37 Enggran Eko Budianto, 'This View Is Castrate Chemistry Problem Ulama in Mojokerto Child Predator',2019.

38 Arah.com, 'MUI Agrees Castration Law For Actors of Sexual Violence', 2016.
} 
children in the perspective of fiqh entered the realm of ta'zir law (not punishments such as stoning, qișās, and similar penalties). Chemical castration punishment is not contested because chemical castration punishment is included in the realm of $t a^{\prime} z \bar{i}$ which must meet two principles. The principle, the benefit is whether chemical castration can suppress the number of sexual crimes against children. Until now there is no valid data that can be used as a reference. Because of these benefits can not be ascertained form. Secondly, it does not harm doomed people. The application of chemical castration for pedophiles does not only damage the reproductive function but also can damage the body's metabolism and health. Therefore, the safety of people convicted with chemical castration is not met ${ }^{39}$ Because these two principles are not fulfilled, chemical castration must not be applied.

Various opinions that arise about the implementation of castration punishment for pedophiles. This can occur because chemical castration punishment is a domain of ta'zir and it is in accordance with their respective ijtihād by looking at the benefits and interpretations that arise from the implementation of chemical castration punishment. can be executed because of the pros and cons of the application of chemical castration punishment.

\section{Conclusion}

Chemical castration has been applied by many countries before Indonesia applied it to pedophiles. Chemical castration is done by taking pills or injections of anti-androgen chemicals that can weaken the hormone testosterone and are not permanent. Among the types of punishment for pedophiles are the most severe penalties and chemical castration punishment is applied. In this case, there is already a sentence for pedophiles established by the East Java District Court Judge. Even though there is already a legally binding law, there is a refusal by the doctors to execute it. Doctors use the Code of Ethics to refuse the execution of chemical castration sentences.

The majority of scholars forbade castration for humans, namely castration which is done by removing or amputating the testes. Castration is contrary to Islamic principles, to continue the descent. Chemical castration from the

${ }^{39}$ Ahmad Muntaha A. M, 'Fiqh Problem of Chemical Castration', Jawa Pos, n.d. 
perspective of classical scholars does not discuss it. Various opinions have emerged about the application of chemical castration for pedophiles. If the castration chemical punishment is temporary, then it can be punished with ta'zir punishment, namely the execution of the sentence handed over to a valid government agreement.[a]

\section{BIBLIOGRAPHY}

Abdul Wahid and Muhammad Irfan. Protection of Victims of Sexual Violence Advocacy for Women's Human Rights,. Bandung: Refika Aditama, 2001.

Abdullah, Arif Tio Buqi. 'Facts of the Aris Predator Case for Children, Sentenced to Chemical Castration Punishment, Asks to Be Sentenced to Death to File a PK'. Tribunnews.com, n.d.

Adam Yuriswanto and Ahmad Mahyani. 'Castration Law as Additional Crimes in the Criminal Act of Sexual Crimes'. Law Journal of Law 14 (2018): 28-40. https://doi.org/10.5281/zenodo.1188350.28.

Arah.com. 'MUI Agrees Castration Law For Actors of Sexual Violence', 2016.

Auda, Jasser. Maqasid Al-Shari'ah as Philosophy of Islamic Law: A Systems Approac. Herndon: The International Institute of Islamic Thought, 2010.

Azizan, Muhammad Fathurrahman bin. 'Castration Punishment for the Criminals of Pedophilia (Comparative Study of Islamic Law According to Classical Ulama and Perppu Number 1 Year 2018)'. UIN Ar Raniri, 2018.

Beritatagar.id. 'Pedophiles in Kendari Were Sentenced to 20 Years in Prison'. 8 October 2019, n.d.

Budianto, Enggran Eko. 'This View Is Castrate Chemistry Problem Ulama in Mojokerto Child Predator', 2019.

Al-Ghazzālī, Abū Ḥāmid Muhammad Ibn Muḥammad. Al-Mustașfā Min 'Ilm alUșūl. Madinah: al-Jāmi'ah al-Islāmiyyah, n.d.

Hariyanto. The Socio-Psychological Impact of Victims of Rape Against Women. Yogyakarta: Pusat Studi Wanita Universita Gajah Mada, 1997.

Ilyas, Sufyan. 'Chemical Castration Sanctions for Pedophiles in the Legal Perspective in Indonesia'. Al Mursalah Journal 1, no. 2 (2015): 54-62.

Indonesia, CNN. 'Komnas Perempuan: Every Day, 8 Women Are Raped in Indonesia'. CNN Indonesia, n.d. 
Jawhar, Aḥmad al-Mursi Ḥusayn. Maqāṣid al-Sharīah fi al-Islām, n.d.

Jawa Pos. 'Police Check the Mental Condition of Bang Jack, Predator 19 Children in Tulungagung', n.d.

Kompas.com. 'Chemical Castration for 9 Child Rapists Was Carried out at the End of the Sentence'. Kompas.com, 2019.

Krismiyarsi. 'Chemical Castration Sanction Policy for Actors of Sexual Violence against Children, Study of Legal Politics'. Unnes 4, no. 1 (2018).

Kristiani, Ni Made Dwi. 'Sexual Violence Crimes (Rape) Viewed From a Criminological Perspective'. Journal of Magister Hukum Udayana 7, no. 3 (2014).

Ligina, Neng Lani, Ai Mardhiyah, and Ikeu Nurhidayah. 'The Role of Parents in the Prevention of Sexual Violence against Children in Elementary School in the City of Bandung'. Ejournal UMM 9, no. 2 (2018): 109-18.

M.liputan6.com. 'PN Mojokerto: Castration Sentence Against Child Rapists with Law'. Surabaya.Liputan6.com, n.d.

M, Ahmad Muntaha A. 'Fiqh Problem of Chemical Castration'.Jawa Pos, n.d.

Madnur. 'Castration Sanctions in Indonesia in the Perspective of Islamic Law and Child Protection'. UIN Syarif Hidayatullah, 2019.

Manafe, Imanuel Nicolas. 'For the First Time in Mojokerto, Judge Sentenced to 9 Child Rapists with Chemical Castration Punishment'. Tribunnews.com, n.d.

Mardiya, Nuzul Qur'aini. 'Application of Chemical Castration Punishment for Perpetrator of Sexual Violence'. The Constitutional Journal 14, no. 1 (2017): 18.

Mardliya, Nurul Qur'ani. 'The Application of Castration Punishment for Sexual Violence'. Constitutional Journal 14, no. 1 (2017).

Marzuki, Suparman. Sexual Harassment. Yogyakarta: Faculty of Law Indonesian Islamic University, 1997.

Merdeka.com. 'Cases of Chemical Castration from Korea to the United States', n.d.

Merriam-Webster. 'Pedophiles Abuse 6 Children in Kendari, This Is Why People Become Pedophiles', n.d.

Nur Hafizal Hasanah and Eko Soponyono. 'Criminal Law Policy on Chemical Castration Sanctions in the Perspective of Human Rights and Indonesian Criminal Law'. Udayana Magister Law Journal 14, no. 1 (2014). 
Nurhayati. Modern Age Slavery: Trafficking in Perspectives of Ulama. Medan: Perdana Publishing, 2016.

Nurliza Fitriyani, Muhammad Hamdan and Mohammad Eka. 'Chemical Castration Acts for Sexual Crimes against Children According to Islamic Law Enforcement Officials'. Jurnal Usu, n.d.

President of the Republic of Indonesia. Government Regulation in Law of The Republic of Indonesia Number 1 of 2016 Concerning The Second Amendment to Law Number 23 of 2002 Concerning Child Protection (2016).

Qudāmah, Ibn. Rawḍh al-Nāẓir wa Jannah al-Manāzirir fi Ușūl al-Fiqh . Riyad: Maktabah al-Rushd, 1993.

Rachmawati, Evy. 'The Dark Side of Tourism on the Island of the Gods', n.d.

Ratnasari, Melina Dwi. "The Views of Nahdlatul Ulama and Muhammadiyah of East Java on the Implementation of Castration Penalty Sanctions on Pedophilia Actors Based on Law Number 17 Year 2016 and According to Islamic Law'. UIN Sunan Ampel, 2018.

Rosyid, Maskur. Implementasi Konsep Maslahat al-Ṭüf dalam Fatwa MUI (20052010). 1st ed. Magelang: Ngudi Ilmu, 2013.

Al-Shāțibī, Abū Isḥāq Ibrāhīm bin Mūsā Bin Muḥammad. Al-Muwāfaqāt fi Ușūl Al-Sharīah. Arab Saudi: Dār Ibn ‘Affān, 1997.

Siradj, Said Aqiel. Islam Kebangsaan Fiqh Demokratik Kaum Santri. Jakarta: Pustaka Ciganjur, 1999.

Sukardi, Muhammad. "The Case of Teacher Rapes 34 Students in Bandung, Is It True That Left-Handed Men Tend to Be Pedophiles', n.d.

Sutriyanto, Eko. "The Case of Pedophilia Occurred in Medan, the Perpetrator Was Unexpectedly, the Victim's Own Neighbor'. 22 January 2019, n.d.

Syam, Nur. Madzab-Madzab Antropologi. Yogyakarta: LKiS, 2007.

Tirto.id. 'KPAI Highlights Cases of Sexual Violence against Children in East Java during 2018'. tirto.id, n.d.

Tribunnews.com. "The First Chemical Castration Penalty For Child Rapists Cannot Be Implemented Without Technical Instructions'. Tribunnews. com, n.d.

Weda, Made Darma. Criminology. Jakarta: Raja Grafindo Persada, 1996. 